\title{
Opettajat aikuisten maahanmuuttajien perustaitoja kehittämässä
}

Artikkelissa tarkastellaan, miten aikuisten maahanmuuttajaopiskelijoiden opettajat ymmärtävät perustaidot ja opiskelutaidot sekä miten he pedagogisoivat perustaitojen opetusta arvioinnin avulla. Perustaitoja ovat luku- ja kirjoitustaidot, numeeriset taidot ja ongelmanratkaisutaidot teknologisesti kehittyneissä ympäristöissä. Aineisto kerättiin opettajien täydennyskoulutuksessa ja se koostuu opettajien laatimista arviointi- ja oppimistehtävistä sekä reflektoinneista. Aineisto analysoitiin teoriaohjaavalla sisällönanalyysilla. Tulosten mukaan täydennyskoulutukseen osallistuneet opettajat näkivät perustaidot usein toisistaan erillisinä eivätkä välttämättä huomioineet aikuisten maahanmuuttajaopiskelijoiden informaaleissa ympäristöissä hankkimia taitoja. Opettajien ymmärrys opiskelijoiden resursseista ja taitojen limittäisyydestä syveni koulutuksessa, ja he rakensivat sen myötä oppimistavoitteita ja -tehtäviä aiempaa funktionaalisemmiksi. Monipuolista oppimista ohjaavaa arviointia oli kuitenkin yhä haastava toteuttaa.

Asiasanat: aikuiskoulutus, maahanmuuttajat, perustaidot

Aikuiskasvatus 41(3), 208

\section{Teachers helping adult immigrants to improve basic skills}

The article examines what teachers of adult immigrant students understand by 'basic skills' and 'study skills', and how they form the pedagogy of basic skills based on assessments. Basic skills include literacy, numeracy, and problem-solving skills, in technologically advanced environments. The data was collected during supplementary professional training for teachers. It consists of assessments and learning tasks that the participating teachers had prepared, and of the teachers' reflections. The data was analysed using theory-related content analysis. The results show that the participating teachers often considered each basic skill in isolation. They did not necessarily take account of the skills that adult immigrant students had acquired informally. During the training, the teachers' understanding of students' resources and overlaps in skills deepened, and they were setting more functional learning goals and tasks than before. However, it was still challenging to implement manysided assessments that would guide learning.

Keywords: adult education, basic skills, migration

Aikuiskasvatus 41(3), 208 


\section{Opettajien kokemuksia työn tuunaamisesta koira-avusteisen pedagogiikan avulla - Tarkastelussa työn vaatimukset, työn voimavarat ja hyvinvointi työssä}

Artikkelissa tutkitaan opetustyön tuunaamista ja sitä, miten opettajat kokevat sen vaikuttaneen työn vaatimuksiin ja voimavaroihin sekä hyvinvointiin. Työn tuunaamisen tapa on koira-avusteisen pedagogiikan hyödyntäminen opetustyössä. Aineisto kerättiin haastattelemalla 14 opettajaa, joilla oli kokemusta koira-avusteisesta työstä. Tulokset osoittivat, että työn tuunaamisella työn vaatimukset ja voimavarat sekä lisääntyivät että vähenivät. Pääosin opettajat kokivat muutokset myönteisinä. Vaikka esimerkiksi työn suunnittelu vaati aiempaa enemmän aikaa, koiran läsnäolo luokassa paransi ilmapiiriä, minkä kuvattiin lisänneen hyvinvointia. Kielteisiksi koettuja muutoksia oli vähän, mutta niiden vaikutukset olivat hyvin kielteisiä. Tilanteet koskivat sosiaalisia suhteita ja kielteisiä asenteita koira-avusteista työtä kohtaan. Koiran kanssa työskentely vaikutti positiivisesti opettajien hyvinvointiin muillakin tavoin, esimerkiksi koiran silittämisen koettiin laskevan stressiä. Työyhteisöissä tulisi suhtautua ennakkoluulottomasti erilaisiin työn tuunaamisen tapoihin, sillä näin työntekijän hyvinvointi voi merkittävästikin kohentua. Työn tuunaamisen reunaehdot ja vaikutukset sidosryhmiin tulisi selvittää, sillä epäonnistuessaan menetelmä voi aiheuttaa pettymystä ja työpaikan vaihtoajatuksia.

Asiasanat: ammatillinen kehitys, koira, koira-avusteinen työ, opetusala, pedagogiikka, työhyvinvointi, työn tuunaaminen, työn vaatimukset, työn voimavarat

Aikuiskasvatus 41(3), 222

\section{Job crafting with help of dog-assisted pedagogy - Job demands and resources and well-being at work}

The article examines teachers' job crafting and how teachers perceive it to have affected their resources and well-being as well as the demands at work. As a method of job crafting, utilizing dog-assisted pedagogy in teaching is examined. The data was collected by interviewing 14 teachers with experience in dog-assisted pedagogy. The results show that the teachers perceived that their job demands and resources had both increased and decreased through job crafting. The changes were perceived mostly as positive. For example, although planning of lectures required more time than before, the presence of a dog in the class improved the atmosphere and thus increased well-being. Also, there were few changes perceived as negative. Teachers had strongly negative experiences in some situations that were related to social relations and to negative attitudes towards dog-assisted work. Moreover, teachers perceived that working with a dog had a positive effect on their wellbeing, e.g., petting the dog relieved stress. Organizations should be open-minded towards different ways of job crafting as they can have a significantly positive effect on employees' perception of job demands, job resources and well-being. On the other hand, the boundary conditions for job crafting and its implications for different stakeholders should be carefully explored, as a failure of or a missed opportunity for job crafting can lead to a disappointment and even to an intention of changing jobs.

Keywords: demands of work, dog, dog-assisted work, education and training, job crafting, job demands, job resources, pedagogy, professional development, teaching sector, well-being at work

Aikuiskasvatus 41(3), 222 


\section{Yleiset valmiudet korkeakoulujen tutkinto-ohjelmien osaamistavoitteissa neljällä koulutusalalla}

Osaamistavoitteiden määritteleminen on osa Bolognan prosessia, Eurooppalaisen korkeakoulutusalueen rakentamista ja tutkintojen tuoman osaamisen vertailtavuuden tavoitetta. Sisältöosaamien lisäksi tärkeiksi ovat nousseet työelämävalmiudet eli niin sanotut yleiset valmiudet. Tarkastelemme yleisiä valmiuksia neljän koulutusala-arvioinnin yhteydessä kerätyissä tutkintokohtaisissa vahvistetuissa osaamistavoitteissa $(\mathrm{N}=628)$. Kuvaamme, millaisia yleisiä valmiuksia korkeakoulujen eri koulutusalojen osaamistavoitteissa oli sekä millaisia alakohtaisia ja korkeakoulusektoreiden välisiä eroja niissä oli. Aineistot analysoitiin monimenetelmällisellä otteella, joka alkoi laadullisella sisällönanalyysillä ja jatkui määrällisellä tarkastelulla. Yleisten valmiuksien kuvausten laaja kirjo ulottui työs- sä pärjäämisen valmiuksista kestävään kehitykseen. Osaamistavoitteiden kirjoittamistavat vaihtelivat. Yleisten valmiuksien tavoitekuvaukset erosivat jonkin verran koulutusaloittain. Ammattikorkeakoulujen tavoitteet olivat konkreettisempia kuin yliopistojen asettamat tavoitteet. Eniten määriteltiin tutkimusta sekä tutkimus-, kehittämis- ja innovaatiotoimintaa (TKI) koskevia valmiuksia ja työelämässä pärjäämisen valmiuksia. Vähiten sijaa saivat kestävän kehityksen valmiudet ja opintojen prosessivalmiudet.

Asiasanat: Bolognan prosessi, korkea-asteen koulutus, korkeakoulututkinnot, osaaminen

Aikuiskasvatus 41(3), 236

\section{General competencies in higher education degree programmes' intended learning outcomes in four fields of study}

Defining the intended learning outcomes is part of the Bologna process that is establishing the European Higher Education Area (EHEA) and aiming at making qualifications comparable. In addition to substance knowledge and competencies, generic competencies have gained increased importance. In the article, we examine general competencies among intended learning outcomes of higher education degrees, gathered in four field-specific education evaluations $(\mathrm{N}=628)$. Our aim was to analyse the generic competencies in the different fields of study and at the two types of higher education institutions (universities and universities of applied sciences). The data was analysed with a mixed methods approach, starting with qualitative content analysis, followed by a quantitative analysis. The range of descriptions of generic competencies was wide, from specific work-related skills to sustainable development skills. The way of defining the intended learning outcomes varied, and descriptions of the outcomes of the general competencies differed by field of education. The intended learning outcomes set by the universities of applied sciences were more concrete than those set by the research universities. The most commonly defined generic competencies were related to research and RDI (Research, Development and Innovation) or to requirements for work. Skills related to sustainable development and study process were mentioned the least.

Keywords: Bologna process, competence, higher education degrees, qualifications, tertiary education Käännös ja toimitus: Esko Clarke Sario

Aikuiskasvatus 41(3), 236 